\title{
The Effect of Job Satisfaction on Organizational Commitment and Work Discipline
}

\author{
Tutik Winarsih ${ }^{1}$, Fariz ${ }^{2}$ \\ ${ }^{1,2}$ Management Study Program, Sekolah Tinggi Ilmu Ekonomi YAPAN, Indonesia \\ twinarsih@stieyapan.ac.id,fariz@stieyapan.ac.id
}

\begin{abstract}
This study examined the effect of job satisfaction on organizational commitment and discipline of work, as well as determined the effect of organizational commitment to the discipline of work. This study involved the lecturers of STIE YAPAN Surabaya. Data analysis that was used in this research was the analysis of the path (path analysis) where confirmatory factor analysis was conducted previously to confirm the indicators that described the construct or variable. The results of confirmatory factor analysis proved that all of the indicators used in this study were not deleted and all the indicators were able to explain the variable job satisfaction, organizational commitment and work discipline. The results of path analysis (path analysis) explained that satisfaction effects on organizational commitment, commitment affects the discipline, and job satisfaction affects work discipline. Theoretical implication of this study is that the study supports the theory that when the lecturers feel more satisfied, they will be more commit and discipline. The practical implications of this study are expected to be a material consideration to STIE YAPAN Surabaya foundations in policy and decision making related to job satisfaction, organizational commitment and work discipline. The advice that can be given to the foundation is increasing attention to the dimensions of salary, normative commitment, and discipline work as dimensions that have bad perception.
\end{abstract}

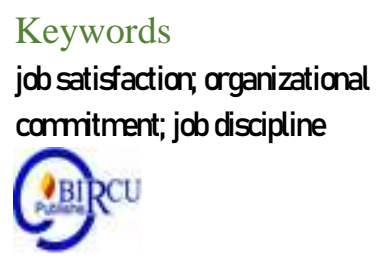

\section{Introduction}

There are many theories about job satisfaction discussed in previous research. One of the well-known theories is the two-factor theory by Herzberg. In Furnham et al. (2009), the two-factor theory is a job satisfaction theory which suggests that satisfaction and dissatisfaction are part of a different group of variables, namely motivators and hygiene factors. . Many impacts will arise if a person is satisfied with his place of work. One effect is on that person's organizational commitment. Gunlu et al. (2009) in their research found a positive relationship between job satisfaction and organizational commitment. Naderi (2011) in his research found a significant positive correlation between job satisfaction and organizational commitment. Silva (2006) found a significant relationship between job satisfaction and organizational commitment. When a person's job satisfaction increases, at that time organizational commitment will also increase.

Apart from affecting organizational commitment, job satisfaction also affects work discipline. Lange (2008) found that employee discipline, attitudes, values and beliefs indicate perceived satisfaction. The more satisfied an employee is, the better his discipline, attitude, values and beliefs will be. According to research conducted by Maryadi (2012), it shows that there is a significant influence between job satisfaction against work discipline. 
Someone who is satisfied will have a positive attitude with his work, so as to spur work discipline to be good.

There are several factors that affect discipline in addition to job satisfaction, one of which is organizational commitment. Haarr (1997) proved that in organizations and fields of work, for example the Police, organizational commitment is a mediating variable to explain the disciplinary behavior of officers (police) when on patrol. Gilder (2003) in his study revealed that someone who has been committed for a long time at work will have better discipline than those who are just starting to commit at work. Chan (2006) found that high commitment from group members will encourage and motivate them to work better.Highly committed members will accept each other, learn from other members, and fully participate in all organizational activities. They will establish norms for dealing with other undisciplined members, such as what to do if members do not attend a meeting or how to deal with absent members.

YAPAN College of Economics is one of the private universities in Surabaya. The YAPAN College of Economics is part of the Palapa Nusantara Foundation, has three study programs namely Management, Accounting and Master of Management with all Accredited B Study Programs (Fariz, 2019). From the results of interviews with 30 foundation lecturers in the YAPAN College of Economics, information was obtained about the complaints of the foundation lecturers. The things that most complain about are work environment and compensation.

The results of the interviews showed that $57 \%$ of foundation lecturers complained about a poor work environment, 33\% considered the work environment to be quite good, and the remaining 10\% considered the work environment good. Aspects of the work environment that are not in accordance with the expectations of the foundation lecturers are caused by the lack of availability of supporting devices for teaching and learning activities such as LCD. Not all lecturers get LCD due to the limited number. In addition, some LCDs were damaged so they couldn't be used.

Apart from the work environment, another thing that foundation lecturers often complain about is compensation, where $53 \%$ of the lecturers complained about poor compensation, $27 \%$ considered it quite good, while $20 \%$ thought it was good. The aspect most frequently complained about is the lack of an increase in compensation. Foundation lecturers at STIE YAPAN expect an increase in compensation in line with the increasingly expensive necessities of life. They also want to provide health benefits.

From these data it can also be seen that foundation lecturers at STIE YAPAN are not satisfied with both the work environment and compensation. Tranggono and Kartika (2008) state that the joy that a person feels has a positive impact on him. If someone is satisfied with the work he is doing, then a sense of joy will come, apart from feeling depressed, so that it will create a sense of security and comfort to always work in his work environment.

Apart from that from the results of direct observation it was found that though have gone through a meeting invitation letter or letter to participate in an activity, Not all foundation lecturers fulfill the invitation and even seem reluctant for various reasons or without reason, there are those who join the activity but incomplete, some even only filled out the attendance list.

From the results of interviews with 30 foundation lecturers in the STIE YAPAN environment, information was also obtained that as many as 60 percent of the foundation's lecturers would accept offers for teaching jobs elsewhere if an offer came to them, and the remaining 40 percent of foundation lecturers rejected the offer. Other data obtained by the author is that 57 percent of foundation lecturers in the STIE YAPAN environment also 
teach elsewhere, and the remaining 43 percent of foundation lecturers only teach in the STIE YAPAN environment. Cotton and Tutle in Wei Amy (2009) stated that employees who are dissatisfied with work or have no commitment to the organization have the possibility to leave the company.

Based on the background of the problems above, the problem formulation or the purpose of this study is to test and analyze whether job satisfaction has a significant direct effect on organizational commitment; whether job satisfaction has a significant direct effect on work discipline; and whether organizational commitment has a significant direct effect on work discipline.

\section{Review of Literatures}

\subsection{Work Discipline}

According to Siagian (2003), discipline is a managerial action to encourage organizational members to meet the demands of various conditions that must be obeyed. Simamora (2005) explains that discipline is a procedure for correcting or punishing subordinates for violating a rule or procedure. Handoko (2010) defines discipline as a managerial activity to carry out organizational standards. Meanwhile, Rollinson (2000) states that discipline is an action taken against individuals who fail to conform to organizational rules.

Based on some of the opinions above, it can be concluded that discipline is a form of great responsibility for a person for a task given by the leadership of the company and can also be interpreted as giving firm action to employees who do not comply with company regulations.

According to Simamora (2005) communication can affect work discipline. Communication is the source of organizational problems. Failure to communicate adequate work standards and expectations is one of the triggers for discipline, so that communication affects employee work discipline. According to Haarr (1997), organizational commitment is a mediating variable to explain the disciplinary behavior of officers (police) while on patrol. Officers with low work commitment will tend to manipulate their duties in providing services to the community and take actions that deviate from their obligations. On the other hand, officers with high work commitment will carry out their duties properly according to their responsibilities without any manipulation.

According to Sukirman (2011), there is a relationship positive and significant between job satisfaction and employee work discipline. Employees have good discipline because they like them work and work environment. Unsatisfied employees at work can be caused by inadequate working conditions, lack of opportunities achievers, and lack recognition from superiors. Getting lower satisfaction felt by employees, the weaker sense of discipline they are at work.

\subsection{Job Satisfaction}

Sutrisno (2009) states that job satisfaction is the attitude of employees towards their work towards work situations, cooperation between employees, benefits received at work, and other physical and psychological factors. This attitude towards work is the result of several individual specific attitudes and social relationships outside the individual's job, giving rise to a general attitude of the individual towards the work being carried out. Bhuian and Menguc in James Boles et al. (2007) Job satisfaction is defined as the attitude that individuals have about their job. It is the degree to which people feel positive or negative about the intrinsic aspect and / or extrinsic to a job. Job satisfaction is a pleasant 
and loving emotional attitude to the worker. This attitude is reflected by work morale, discipline, and work performance. And Job satisfaction affects the level of employee discipline, meaning that if satisfaction is obtained from work, good employee discipline (Syardiansah et al, 2020).

Prabu (2005) states that job satisfaction is the difference between the expectations that someone imagines from the contribution of work that has been done and the expected reality. From some of the opinions above, it can be concluded that job satisfaction is a person's response to what is expected at work and what he gets after doing the job. Job satisfaction is related to work situations, cooperation between employees, benefits, and other factors. If there is a small difference between what a person hopes and achieves, he will be satisfied and vice versa.

Job satisfaction theory tries to uncover what makes some people more satisfied with their work than others. This theory also seeks a basis for the process of people's feelings of job satisfaction. In this study, the theory used is the two-factor theory according to Herzberg. Furnham et al. (2009) revealed that the job satisfaction theory states that satisfaction and dissatisfaction are part of a different group of variables, namely motivating factors and cleanliness. In general, people are satisfied when certain factors are available and dissatisfied when they are not available. Based on this theory, dissatisfaction is associated with the surrounding conditions and not with the job itself because this factor prevents negative reactions called hygiene or maintenance factors.

On the other hand, satisfaction comes from factors related to the job itself or a direct result of it, promotion and opportunities for self-development and recognition because these factors are associated with high levels of job satisfaction called motivators. A study entitled "Personality, motivation, and job satisfaction: Herzberg meets the Big Five" conducted by Furnham et al. (2009) investigated the extent to which motivators and hygiene factors could explain variance in job satisfaction as defined in Herzberg's twofactor theory. The results showed that motivating factors and hygiene were prerequisites for job satisfaction.

\subsection{Organizational Commitment}

According to Mathis and Jackson in Sopiah (2008) provide a definition of "Organizational Commitment is the degree to which employees believe in and accept organizational goals and desire to remain with the organization", namely organizational commitment is the degree to which employees believe and accept organizational goals and will stay or will not leave the organization. Swailes in James Boles et al. (2007) explained that organizational commitment reflects positive feelings towards the organization and its values. Basically, measuring organizational commitment is an assessment of the congruence between an individual's own values and beliefs and the organization.

Sees some sense of organizational commitment from several experts, have some in common that can be concluded that commitment organization has the meaning as a loyalty, trust and loyalty that one has against the organization. So this organizational commitment describes the relationship between individuals and organizations, if individuals which has a high organizational commitment, it will have loyalty, trust and loyalty to the organization where he works.

\subsection{The Relationship between Job Satisfaction and Organizational Commitment}

Research Wang (2007), the results of this study indicate that culture Organizational learning can be seen as an important factor for satisfaction employee work and organizational commitment. The results of this study too revealed that job satisfaction is 
positively related to commitment organization, here job satisfaction serves as a benchmark in determining employee emotional response which will have an impact on commitment organization. The employee will be committed to his place of work when the job satisfaction expected by the employee can fulfilled by the company.

The findings of James Boles et al. (2007), illustrates that aspects which shows that job satisfaction is related to affective commitment employees. The aspects of job satisfaction used in this study are promotions, salaries, jobs, supervision of leaders, work groups. Promotion considered by employees as a status that affirms existence they are at work, so employers should consider the importance of promotion in the company. Salary can strengthen commitment to a company, where through the payment of a sufficient salary show an appreciation to its employees, so that employees are satisfied with the payment of his salary will be strong commitment to the company.

Jobs that match the abilities of the workers will make workers is satisfied to work in the workplace so that it raises commitment employees. Supervision of leaders, leaders who carry out the supervision excessive will make employees feel uncomfortable to work, that way also with leaders who are indifferent to their employees will make the employee feels unappreciated by his boss. As a leader better be able to provide an example to employees, if there is a violation rules should be given sanctions and if someone makes an achievement then leaders do not hesitate to praise and reward employees this, so that commitment will emerge among employees.

The results of research conducted by Gunlu et al. (2009), shows that there is a positive relationship between job satisfaction and commitment organization. It can be said that when a person's job satisfaction increases, then at that time their organizational commitment will also increase. So things - things that can create a person's job satisfaction must be very pay attention to where if it is not considered then commitment organization will be reduced. In a study conducted by Naderi (2011), a significant positive correlation was found between job satisfaction and organizational commitment. The logical explanation that can be drawn from this research is that organizational commitment is a function of job satisfaction. Various dimensions of job satisfaction, such as satisfaction with salaries, satisfaction with colleagues, supervision of leaders and jobs itself needed by workers to meet basic needs they. When their needs are met there is a level of organizational commitment they're going to be tall. Based on the research results that have been disclosed, it can the research hypothesis is formulated as follows:

H1: Job satisfaction has a direct positive effect on organizational commitment.

\subsection{The Relationship between Job Satisfaction and Work Discipline}

Muhaimin (2004), from this study, it was found that there was positive relationship between employee job satisfaction and employee work discipline shawing computer operator for production at PT.Primarindo Asia Infrastructure Tbk Bandung. From this study also obtained the results that aspects Job satisfaction both hygiene factors and motivator factors have a correlation with aspects of work discipline. So if in a company, there is employees who have good discipline, this can happen because of employees likes the field of work, the attitude of the boss, the relationship with employees who are well established, there is an award / promotion, and vice versa with employees who have work discipline less.

Research conducted by Maryadi (2012), where the research results shows that there is a significant influence between job satisfaction on work discipline. Teachers who feel satisfied will have a positive attitude with job, so that it can spur performance and automatically discipline it will work fine. However, if the teacher is not satisfied then their 
performance will not be good as will their work discipline which is not good either.

An article from Sukirman (2011), where the author examines the relationship between satisfaction work with work discipline. The results of this article indicate that it is a positive and significant relationship between job satisfaction and work discipline employees. Employees having good discipline can be caused because they like their work and work environment. Less satisfied employees work can be caused by inadequate working conditions, lack of opportunities for achievement, and lack of recognition from superiors.

The lower the satisfaction felt by employees, the weaker it is their sense of discipline at work. Based on the research results that have been disclosed, it can the research hypothesis is formulated as follows:

$\mathrm{H} 2$ : Job satisfaction has a direct positive effect onwork discipline.

\subsection{The Relationship between Organizational Commitment and Work Discipline}

The results of research conducted by Haarr (1997) found that in organizations and jobs such as policing, organizational commitment is mediating variables to explain the disciplinary behavior of officers while on patrol. Officers with low work commitment will manipulate their duties in providing services to the community and tends to do actions that deviate from their duties. Otherwise the officers were highly committed will carry out their duties properly according to their responsibilities he answered without any manipulation.

Research from Chan (2006), in this study Chan found that high commitment from group members will energize and motivate them to do better. Highly committed members will accept each other, learn from other members and participate fully in every activity of the organization. The member will set which member others in terms of actions and behavior, and reminds them of their original purpose join the organization. They will create their norm alone to deal with other undisciplined members, they would develop these norms, like what would be done if members not attending meetings or how to handle absent members. So that members who are highly committed try to maintain discipline them and make other members share their discipline. Based on the research results that have been disclosed, it can the research hypothesis is formulated as follows:

H3: Organizational commitment has a direct positive effect on work discipline

\section{Research Methods}

Based on the objectives that have been set, the research used is explanatory research. Explanatory research is research that explains the causal relationship between variables by submitting hypotheses using the same data. This study uses an explanatory research design to explain the causal relationship or the effect of job satisfaction on organizational commitment and work discipline by testing the hypotheses mentioned above.

While the method used is descriptive survey method, which is a research method that takes a sample from a population and uses a questionnaire as a data collection tool. In this study, data and information were collected from respondents using a questionnaire. After data collection, the results are presented descriptively and at the end of this study analyzed to test the hypothesis formulated at the beginning of this study (Effendi, 2003). In this study, the total population was 30 people, and saturated sampling or census was used, so all permanent lecturers of active foundations at STIE YAPAN Surabaya were sampled / respondents.

Data collection in the field is carried out in the following ways; Questionnaires were distributed to foundation lecturers at STIE YAPAN Surabaya. Respondents answered 
themselves without any intervention by the researcher. Interviews are used as a technique of gathering information by holding questions and answers with related parties. Interviews were conducted with the aim of obtaining additional information used in this study such as complaints and opinions of foundation lecturers.

Path analysis is used to analyze the relationship between variables with the aim of knowing the direct or indirect influence, a set of independent variables (exogenous) to the dependent variable (endogenous). Model Path analysis is a pattern of causal relationships or a set of hypothesized causal asymmetric relations among the variables, Riduwan and Engkos (2010). As stated by Sugiyono (2010). In the causal model, there is a difference between exogenous and endogenous variables. The variables in this path analysis are exogenous variables as causal variables and endogenous variables as effect variables.

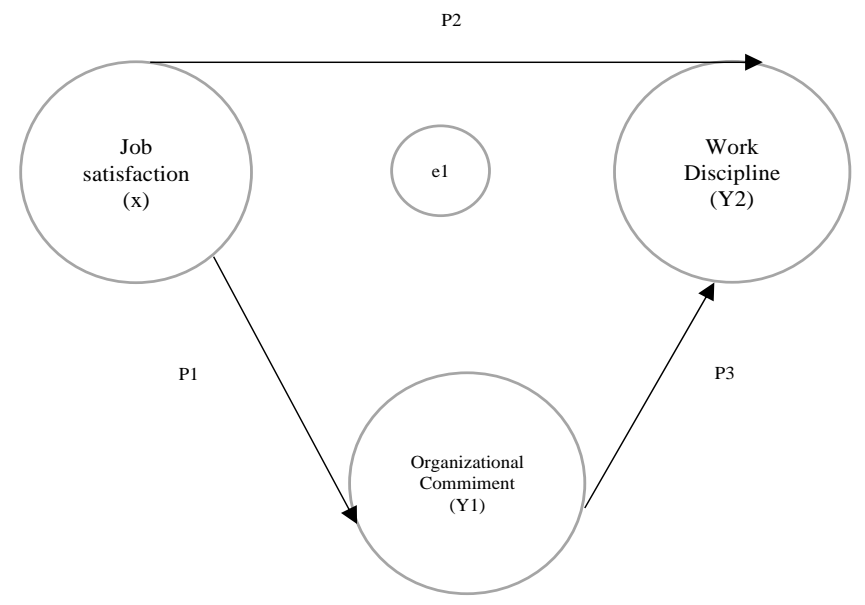

Figure 1. Model Path Analysis

\section{Results and Discussion}

The results of data analysis show that the job satisfaction variable has a positive and significant effect on organizational commitment, seen from the coefficient value of the job satisfaction variable of 0.415 . Job satisfaction is measured by using indicators of satisfaction with the job itself, salary, supervision, promotion, and work relations. Based on the results of the lecturer's assessment, the work assigned to the lecturer is in accordance with their field of expertise lecturers are given the opportunity to develop their potential in STIE; and kinship between lecturers can increase job satisfaction so that lecturers feel better in organizing to carry out their careers. In line with these results, Naderi (2011) found a positive and significant relationship between job satisfaction and organizational commitment. Various dimensions of job satisfaction, such as satisfaction with salaries, satisfaction with colleagues, satisfaction with superior supervision, and satisfaction with the job itself, are needed by colleagues to meet their basic needs. When their needs are met, their level of organizational commitment will also be high.

The results of data analysis also prove that there is a positive and significant relationship between job satisfaction and work discipline as indicated by the coefficient value of the job satisfaction variable of 0.337 . If lecturers are satisfied with various things such as the job itself, salary, supervision, promotion and work relations, then they will be kind to their job, be on time teaching, and are ready to accept sanctions if they violate. In other words, the higher the job satisfaction of the lecturers, the higher the work discipline. Conversely, the lower the job satisfaction of the lecturers, the lower the work discipline 
will be. The condition of lecturers who are satisfied with what they have done for STIE will have an impact on their discipline. Lecturers will be more disciplined both in terms of time and work.

Organizational commitment consists of three dimensions, namely affective, sustainable and normative commitment. The results of the data analysis prove that the variable organizational commitment has a positive and significant effect on work discipline as indicated by the coefficient value of the organizational commitment variable of 0.250 . Commitment is measured using affective commitment, ongoing commitment, and normative commitment. The results showed that the lecturers were satisfied with spending their careers at STIE and found it difficult to leave STIE. The positive effect of this loyalty can increase the commitment of lecturers to be disciplined with all the rules applied in STIE. This result is in line with Chan (2006) who found that high commitment from group members will energize and motivate them to work better. They will set their own norms to deal with other members who are not disciplined. Lecturers with low commitment will manipulate their duties and obligations, tend to take actions that deviate from their duties. On the other hand, lecturers who are highly committed will carry out their duties according to their responsibilities without any manipulation.

This study found that job satisfaction has a positive effect on organizational commitment, organizational commitment has a positive effect on work discipline, and job satisfaction has a positive effect on work discipline. The findings of this study enrich the empirical evidence of the effect of job satisfaction on organizational commitment and work discipline as well as the effect of organizational commitment on work discipline. The results of this study support the theory that if the lecturer is satisfied with the job, salary, supervision, promotion and relationship with fellow lecturers, they will commit to STIE. The more satisfied the lecturer, the more committed and disciplined the lecturer will be.

Based on the results of data analysis, lecturer work discipline is influenced by job satisfaction and organizational commitment. Looking at the results of lecturers' assessment of job satisfaction, organizational commitment and work discipline, it was found that the assessment had little value and had to get more attention from the foundation. Things that need to be considered by the foundation to be able to increase job satisfaction are regarding salaries and allowances that are deemed inadequate and not in accordance with their responsibilities, leaders who give praise to the results of work that has been done, implementation of regulations by leaders and opportunities to occupy different positions.

Things that need to be considered by the foundation to increase organizational commitment is that many things will be disturbed if you decide to leave and it is better to be in the same organization for most of your careers. The thing that needs to be considered by the foundation to improve work discipline is that foundation lecturers feel that there is no consistency in giving sanctions for lecturers who violate and lecturers do not hesitate to commit violations (Fariz \& Winarsih, 2017).

\section{Conclusion}

From the results of data analysis in this study it can be concluded that: Job Satisfaction is positively related to organizational commitment. The positive correlation means that the more lecturers who are satisfied with their work, the more committed they will be to STIE YAPAN Surabaya. Job satisfaction also has a positive correlation with work discipline. This proves that the more lecturers who are satisfied with their work, the more disciplined they will be in carrying out their duties and responsibilities. Organizational commitment has a positive correlation with work discipline. This means 
that with the commitment of lecturers to STIE YAPAN Surabaya, there will be more discipline.

Based on the results of this study, the suggestions that can be given include: To improve the work discipline of permanent lecturers at the STIE YAPAN Surabaya foundation, the foundation needs to pay attention to job satisfaction and lecturers' organizational commitment. In general, lecturer job satisfaction has a good value. However, in an effort to increase work discipline, foundations need to increase salaries and allowances that are deemed insufficient and not in accordance with their responsibilities, leaders who give praise to the results of work that has been done, implementation of regulations by leaders and opportunities to occupy different positions. Meanwhile, things such as the job given are in accordance with the field of expertise, being given the opportunity to develop one's potential in STIE, and having established kinship with fellow lecturers must be maintained because they already have good grades.

Lecturer organizational commitment in general has a good value. However, there are several scores that are still low and need to be improved by the foundation, namely that there are not many things that are disturbed if the lecturer decides to leave and not many lecturers feel that it is better to be in the same organization for most of their careers. Things that must be maintained by the foundation because they have good values is the feeling of a lecturer who is happy to spend his career at STIE, finds it difficult to leave STIE and the value of loyalty has a positive impact. Work discipline in general has a fairly good score, but there is a lowest score that the foundation should raise, namely foundation lecturers feel there is no consistency in imposing sanctions for lecturers who violate and lecturers are not reluctant to commit violations.

Based on the results of this study, the authors are aware that there are limitations in this study. Seeing the results of the calculation of the total coefficient of determination which is 37.9 percent of the data diversity that can be explained by the model. So that the authors recommend in further research to add more new variables, given that 62.1 percent of variables have not been studied in this study.

\section{References}

Adomi E. Esharenana dan Eruvwe Ufuoma. 2004. Staf discipline in Nigerian University Libraries, Library Management, Vol.25.Iss 4.pp 223-229

Allen, Natalie J dan Meyer, John P. 1990. The Measurement and antecendents of affective, continuance and normative commitment to the organization, Journal of Occupational Psychology, Vol 63. Pp 1-18

Azeem, Syed Mohammad. 2010. Job Satisfaction and Organizational Commitment among Employees in the Sultanate of Oman, Scientific Research, Vol 1. Pp 295 - 299

Chan, Sow Hup. 2006. Organizational identification and commitment of members of a human development organization, Journal of Management Development, Vol 25, Iss 3. Pp $249-268$

Chang, Su-Chao dan Lee. Ming-Shing. 2006. Relationships among Personality, Job Characteristic, Job Satisfaction and Organizational Commitment - An Empirical Study in Taiwan, The Business Review, Cambridge, Vol 6, Iss 1. Pp $201-2017$

Chiun Lo, May dan Ramayah, T. 2011. Mentoring and job satisfaction in Malaysian SMEs, Journal of Management Development, Vol 30, Iss 4. Pp 427 - 440

Darwish A. Yousef. 2000. Organizational commitment and job satisfaction as predictors of attitudes toward organizational change in a non-western setting, Personal Review, Vol 29 Iss : 5 pp 567 - 592 
Donna McNeese, Smith. 1996. Increasing Employee, Job Satisfaction and Organizational Commitment, Journal Of Healthcare Management, Summer 41, No 2. Pp 160 - 175

English, Brian., Morrison, David., Chalon, Christoper. 2010. Moderator effects of organizational tenure on the relationship between psychological climate and affective commitment, Journal of Management Development, Vol 29 Iss 4 pp 394 - 408

Fadilla Helmi, Avin. 1996. Disiplin Kerja, Buletin Psikologi, Tahun IV, Nomor 2

Fariz. (2019). Human Resources Competences in Economics Higher Education Provider in East Java, Indonesia: The determinant of organizational performances. Asia-Pacific Management and Business Application, 8(2), 133-144. https://doi.org/10.21776/ub.apmba.2019.008.02.5

Fariz, \& Winarsih, T. (2017). Effect Analysis of Student Perceptions on Service Quality to Student Loyalty in Management Master Program of Sekolah Tinggi Ilmu Ekonomi YAPAN. Russian Journal of Agricultural and Socio-Economic Sciences, 67(7), 133141. https://doi.org/10.18551/rjoas.2017-07.16

Furnham, Adrian., Eracleous, Andreas., Premuzic, Tomas Chamorro, 2009. Personality, motivation and job satisfaction: Hertzberg meets the Big Five, Journal of Managerial Psychology, Vol 24, Iss 8 pp 765-779

Gilder, Dick de. 2003. Commitment, trust and work behavior The case of contingent workers, Personnel Review, Vol 32, No 5 pp 588 - 604

Gouzali, Saydam. 2002. Manajemen Sumber Daya Manusia. Jakarta: PT. Gunung Agung

Gunlu, Ebru., Aksarayli, Mehmet., Sahin Percin, Nilufer. 2010. Job satisfaction and organizational commitment of hotel managers in turkey, International Journal of Contemporary Hospitality Management, Vol 22, Iss 5 pp $693-717$

Haarr N, Robin. 1997. "They're making a bad name for department": Exploring the link between organizational commitment and police occupational deviance in a police patrol bureau, policing: An International Journal of Police Strategies \& Management, Vol 20, Iss 4 pp $786-812$

Handoko, Hani. 2010. Manajemen Personalia dan Sumber Daya Manusia. Yogyakarta: BPFE

Henry, Simamora. 2005. Manajemen Sumber Daya Manusia. Yogyakarta: Penerbit Andi

Irawati, Dwi dan Mustakim, Noor. Pengaruh Komitmen Organisasional, DisiplinKerja dan Motivasi Kerja Terhadap Prestasi Kerja Pegawai Balai Pelaksana Teknis Bina Marga Wilayah Magelang

James Boles, Ramana Madupalli, Brian Rutherford, John Andy Wood. 2007. The Relationship of Facets of Salesperson Job Satisfaction With Affective Organizational Commitment, Journal of Business \& Industrial Marketing, Vol 22 Iss 5 pp 311 - 321

Jha, Sumi. 2011. Influence of psychological empowerment on affective, normative and continuance commitment: A study in the Indian IT industry, Journal of Indian Business Research, Vol 3 Iss 4 pp 263 - 282

Johan, Rita 2002. Kepuasan Kerja Karyawan dalam Lingkungan Institusi Pendidikan, Jurnal Pendidikan Penabur, No.01

Lange, Thomas. 2008. Attitudes, attributes and institutions determining job satisfaction in central and Eastern Europe, Employee Relations, Vol 31.. No 1 pp 81 - 97

Lok, Peter dan Crawford, John. 1999. The relationship between commitment and organizational culture, subculture, leadership style and job satisfaction in organizational change and development, Leadership \& Organization Development Journal, Vol 20 Iss 7 pp 365 - 374 
Maryadi. 2012. Pengaruh budaya organisasi, Kompensasi, dan Kepuasan Kerja Terhadap Dsiplin Kerja Guru SD di Kecamatan Tengaran Kabupaten Semarang, JMP, Volume 1 Nomor 2, hal $177-188$

Meyer, John P., Stanley, David J., Herscovitch, Lynne., and Topolnytsky, Laryssa. 2002. Affective, Continuance, and Normative Commitment to the Organization: A Metaanalysis of Antencendents, Correlates, and Consequences, Journal of Vacational Behavior, Vol 6 pp $20-52$

Minnesota Satisfaction Questionnaire. 1967. Vocational Psychology Research. University Of Minnesota

Mottaz J, Clifford. 1998. Determinants of Organizational Commitment. Human Relations, Vol 41. Number 6 pp $467-482$

Muhaimin. 2004. Hubungan Antara Kepuasan Kerja Dengan Disiplin Kerja Karyawan Operator Shawing Computer bagian produksi pada PT. Primarindo Asia Infrastruktur Tbk di Bandung, Jurnal PSYCHE, Vol 1, No 1

Naderi Anari, Nahid. 2012. Teachers: emotional intelligence, job satisfaction, and organizational commitment, Vol 24, Iss 4 pp $256-269$

Nelson A. Silvia. 2012. Affective Commitment of generational cohorts of Brazilian nurses. Journal of Manpower, Vol 33, Iss 7 pp $804-821$

Noor Arifin, Komaruddin. 2009. Analisis Pengaruh Kepemimpinan, Kapabilitas, Komitmen Terhadap Kinerja Anggota Satuan Komando Distrik Militer 0719 Jepara, Jurnal Dinamika Ekonomi \& Bisnis, Vol 6, No. 2 pp 172 - 186

Prabu, Anwar. 2005. Pengaruh Motivasi Terhadap Kepuasan Kerja Pegawai Badan Koordinasi Keluarga Berencana Nasional Kabupaten Muara Enim, Jurnal Manajemen \& Bisnis Sriwijaya, Vol 3, No 6. Hal 1 - 25

Ridwan, Kuncoro Engkos Achmad. 2010. Cara menggunakan dan Memaknai Analisis Jalur (Path Analysis). Cetakan Pertama. Bandung: Alfabeta

Rollinson J. Derek. 2000. Supervisor and manager approaches to handling discipline and grievance: a follow - up study, Personal Review, Vol 29, Iss 6 pp $743-768$

Rowden W, Robert. 2000. The relationship between charismatic leadership behaviors and organizational commitment, Leadership \& Organization Development Journal, Vol 21, Iss 1 pp $30-35$

Siagian, S.P. 2003. Manajemen Sumber Daya Manusia. Jakarta : Bumi Aksara Indonesia

Silva, Paula. 2006. Effects of Disposition on Hospitality employee job satisfaction and commitment, International Journal of Contemporary Hospitality Management, Vol 18, No 4 pp $317-328$

Sopiah. 2008. Perilaku Organisasional. Yogyakarta : Penerbit Andi

Sugiyono. 2010. Metode Penelitian Bisnis. Cetakan Kesebelas. Bandung : CV. Alfabeta

Sukirman. Hubungan Kepuasan Kerja Dengan Disiplin Kerja Karyawan Bagian Produksi PT. BINTRATEX Semarang, ISSN : $1979-6889$

Susilo, Martoyo. 2002. Manajemen Sumber Daya Manusia. Yogyakarta : BPFE

Sutrisno, Edy. 2009. Manajemen Sumber Daya Manusia. Jakarta : Kencana

Suyana Utama, Made. 2009. Aplikasi Analisis Kuantitatif. Denpasar : Sastra Utama

Syardiansah, et al. (2020). The Effect of Job Satisfaction and Organizational Culture on Employee Performance of the Royal Hotel in East Aceh District. Budapest International Research and Critics Institute-Journal (BIRCI-Journal). P. 849-857.

Tranggono Probo, Rahadyan dan Kartika. Andi. 2008. Pengaruh Komitmen Organisasional dan Profesional Terhadap Kepuasan Kerja Auditor Dengan Motivasi Sebagai Variabel Intervening (Studi Empiris Pada Kantor Akuntan Publik di Semarang), Jurnal Bisnis dan Ekonomi, Vol 15, No 1 ISNN : 1412 - 3126. Hal 80 - 90 
Wang, Xiaohui. 2007. Learning, job satisfaction and commitment : an empirical study of organizations in china, Vol 1, No 3 pp $167-179$

Wei Amy Tian, Foreman. 2009. Job Satisfaction and Turnover in the Chinese Retail Industry, Chinese Management Studies, Vol 3, Iss 4 pp 356 - 378

Yiing, Lee Huey., Zaman Bin Ahmad, Kamarul. 2009. The Moderating Effect of Organizational Culture on the Relationship Between Leadership Behaviour and Organizational Commitment and Between Organizational Commitment and Job Satisfaction and Performance, Leadership \& Organization Development Journal, Vol 30, Iss 1 pp $53-86$ 